\title{
KONSISTENSI PENDEKATAN SAINTIFIK PADA KONTEN BUKU BAHASA ARAB MI KELAS 6 KURIKULUM 2013
}

\author{
Muhammad Zaairul Haq
}

\author{
Institut Agama Islam Negeri Jember \\ santriclumut@gmail.com
}

\begin{abstract}
Abstrak
Pengembangan dan perubahan apapun terkait pembelajaran merupakan hal wajar dalam sistem pendidikan. Indonesia sendiri telah mengalami hal itu, hingga pada beberapa tahun belakangan berupaya menerapkan pendekatan terbaru pula yaitu pendekatan saintifik dalam proses belajar. Namun demikian proses yang ada ini tidak luput dari kritik, dan kritik menjadi hal yang wjaar pula yang sudah semestinya ada. Diantara kritik yang mengemuka dan banyak digunakan sebagai hipotesis yaitu terkait adanya inkonsistensi dalam penerapan pendekatan saintifik dengan konten pada buku ajar. Penelitian ini kemudian secara khusus mencoba untuk menjawab secara ilmiah hipotesis tersebut dengan mengupas tingkat konsistensi pendekatan saintifik dengan konten pada buku ajar bahasa Arab kelas 6 MI Kurikulum 2013. Metode penelitian yang digunakan yaitu deskriptif-kualitatif dengan melihat berbagai fakta yang ada pada setiap bagian konten buku ajar bahasa Arab kelas 6 MI Kurikulum 2013. Hasil dari penelitian menunjukkan adanya konsistensi terhadap penggunakan pendekatan saintifik, hanya saja bersifat monoton dan cenderung sama pada setiap tema pada masing-masing bab. Hasil penelitian menyarankan kepada pihak terkait agar menyusun buku ajar yang memiliki konten lebih variatif agar peserta didik dapat melakukan eksplorasi terhadap berbagai hal secara lebih luas dan tidak menjemukan.
\end{abstract}

Kata kunci: Konsistensi, pendekatan saintifik, pembelajaran, bahasa Arab

\begin{abstract}
Any developments and changes related to learning are normal in education system. Indonesia itself has experienced this, so in recent years it has tried to apply the latest approach, it is scientific approach in learning process. However, this existing process does not escape criticism, and criticism becomes a natural thing that should exist. Among the criticisms that appeared and widely used as hypotheses were related to inconsistency in application of scientific approach to the content in textbooks. This research specifically tries to answer scientifically the hypothesis by examining consistency level of scientific approach with the content in 6th grade Arabic textbook of MI K13. The research method used is descriptivequalitative by looking at various facts that exist in each section of the content of Arabic textbook for 6th grade MI K13. The results of the study show that there is consistency in the use of scientific approach, but it is monotonous and tends to be same in each theme in each chapter. The results of the study suggest to related parties to compile textbooks that have more varied content so that students can explore various things more broadly and not be boring.
\end{abstract}

Keywords: Consistency, scientific approach, learning, Arabic

Received:2021-3-27 Accepted: 2021-4-29 Published: 2021-6-16 


\section{A. Pendahuluan}

Evaluasi, pengembangan dan perubahan merupakan proses wajar dalam sebuah sistem pendidikan. Sebab bagaimanapun ketatnya sebuah sistem pendidikan, pada hakikatnya tidak lebih sebagai bagian dari sebuah proses sosial yang besar yang diantara ciri khasnya senantiasa membutuhkan perubahan, perkembangan, dan mengalami pergerakan yang tentu di dalamnya menghadapi berbagai kendala, permasalahan dan perolehan hasil atas penyelenggaraan sistem tersebut. Oleh karena itu, memandang perubahan apapun itu termasuk dalam sistem penyelenggaraan pendidikan tentu harus didasari pada prasangka baik dan cita-cita terhadap kemajuan dan kesuksesan bersama.

Termasuk diantara beberapa fenomena pengembangan dan perubahan pada sistem pendidikan itu sendiri yaitu terkait dengan perubahan kurikulum. Sebagaimana diketahui Indonesia merupakan diantara negara yang "secara konsisten" gemar berganti kurikulum mulai tahun 1947 hingga yang terbaru 2013. Pemicunya bermacam-macam, mulai dari isu politik, sosial, budaya, dan murni karena dinamika pendidikan. Apapun itu perubahan tetap perubahan yang artinya ini merupakan dinamika yang wajar namun bukan berarti kewajaran itu harus anti terhadap kritik. Kritik tetap dilakukan namun perlu dibedakan antara fenomena perkembangan dan perubahan dengan kritik itu sendiri. Kritik merupakan satu hal, sedangkan perkembangan dan perubahan merupakan hal lain. Hanya saja ada satu hal yang harus diperhatikan sebagaimana pesan dari Hasan Langgulung, yakni sedalam apapun perkembangan dan perubahan yang terjadi, suatu kurikulum harus bermula dengan nilai-nilai tertentu yang menjadi tujuan kurikulum itu dibentuk. Dengan demikian diharapkan nilai-nilai ini kelak akan menjadi dasar pembentukannya, pemilihan prioritas yang harus ditekankannya, dan manusia yang bagaimana akan dibentuk menurut pendidikan tersebut. ${ }^{1}$

Selanjutnya, di dalam konsep kurikulum 2013 sebagai kurikulum terbaru saat ini, ada beberapa falsafah dasar yang perlu dipahami terlebih dahulu bahwa kurikulum ini menghendaki adanya konsep khusus beserta implementasi nyata terkait pengembangan kompetensi tertentu pada peserta didik. Dari titik ini sudah dapat dipahami bahwa pengembangan kurikulum ini merupakan bagian dari usaha untuk mewujudkan sumber daya manusia yang cerdas, aktif, inovatif, trampil dan mampu menjawab tantangan peradaban modern yang identik dengan kemajuan teknologi dan

${ }^{1}$ Hasan Langgulung, Manusia \& Pendidikan Suatu Analisa Psikologis, Jakarta: PT. Al Husna Baru, 2004.hlm. 194 
komunikasi. Penerapan pembelajaran pada lembaga pendidikan formal dalam berbagai tingkat mulai SD, SMP, hingga perguruan tinggi menghendaki adanya formulasi yang memang dibutuhkan untuk semua itu. Hal ini pada akhirnya memicu bagi munculnya pendekatan saintifik atau scientific approach pada proses pembelajaran.

Secara spesifik pendekatan saintifik merupakan bentuk pendekatan yang berupaya menguatkan proses pembelajaran di kelas yang aktif dan solutif sesuai tuntutan zaman. Ini artinya mulai pada persoalan teknis proses pembelajaran di kelas, pendekatan ini berupaya untuk membentuk pola belajar mandiri, cara berfikir ilmiah, dan prinsip-prinsip edukasi yang menekankan kreatifitas daripada sekedar doktrinasi. Demikian pula pada pengembangan media pembelajaran semisal buku ajar, pendekatan saintifik berupaya menciptakan konsistensi konten yang seirama antara falsafah, konsep, proses, teknis, dan konten media buku ajar itu sendiri. Namun demikian ternyata pada tataran implementasi di lapangan, prinsip-prinsip seharusnya ada pada pendekatan saintifik menjadi bias dan dianggap tidak sesuai antara teori dan implementasi sehingga mengundang banyak pertanyaan, keraguan dan ketidakpercayaan. Bahkan tidak sedikit opini yang muncul ke publik cenderung menarasikan adanya penolakan terhadap pendekatan ini secara total. Ada banyak sisi yang diangkat, mulai dari motif penyelenggaraannya sendiri, hingga pada adanya inkonsistensi pada beberapa hal terkait yang seharusnya menjadi satu kesatuan yang seirama dan saling mendukung satu sama lain. Walhasil, fenomena kritik yang banyak mengemuka ini menjadi lingkup kajian yang perlu diangkat untuk setidaknya sebagai bagian dari upaya ilmiah yang mengedepankan objektifitas yang dapat dipertanggungjawabkan. Adapun kajian pada penelitian ilmiah ini hendak melihat dan mengupas tentang sejauh mana konsistensi penggunaan pendekatan saintifik antara tataran konsep dan implementasinya pada penyusunan buku ajar bahasa Arab kelas 6 MI.

Pada tataran teoritis pendekatan saintifik menekankan pada lima langkah pembelajaran yang sangat penting dan mendasar, yaitu observing, questioning, associating, experimenting, dan networking. Pada pendekatan ini tujuan pembelajaran fokus pada pembangun pemahaman peserta didik untuk memahami suatu materi menggunakan pendekatan ilmiah dengan proses belajar yang mendorong peserta didik untuk tidak hanya diberi tahu begitu saja oleh guru, namun juga mencari tahu melalui 
observasi. Untuk itu pendekatan ini menawarkan beberapa keterampilan mendasar yaitu melakukan pengamatan, kemudian klasifikasi, pengukuran, peramalan, menjelaskan, dan terakhir menarik suatu simpulan.

Pada sisi paling dasar ini, pengamatan terhadap konsistensi penggunaan pendekatan saintifik pada proses belajar mengajar akan mudah untuk dibaca dan dilihat. Hal ini mengingat bahwa buku ajar sebagai media pembelajaran merupakan bagian yang paling penting dalam penyelenggaraan kegiatan belajar mengajar. Bahkan ia menjadi bagian dari unsur utama kurikulum yang di dalamnya memuat empat aspek. Hasan Langgulung membahasakannya dengan empat aspek utama yang harus ada dan terkait erat satu sama lain, yaitu; tujuan pendidikan, knowledge, metode dan cara-cara mengajar (termasuk media pembelajaran/buku ajar), dan metode atau cara penilaian. ${ }^{2}$ Sebagai bagian dari unsur utama kurikulum, buku ajar menjadi wajar apabila memiliki fungsi utama sebagai sumber acuan atau buku ajar sebagai buku pegangan yang menjadi sumber acuan pendidik dan peserta didik dalam belajar. Oleh karena itu buku ajar memiliki potensi yang sangat besar dalam memberikan pengaruh terhadap hal-hal teknis pembelajaran hingga pada titik arah tertentu yang menjadi tujuan akhir dari suatu pembelajaran itu sendiri. Santika melihat buku teks bahkan mampu mempengaruhi sikap pembaca. ${ }^{3}$

Buku ajar bahasa Arab MI kelas 6 sebagai rujukan utama dalam proses pembelajaran bahasa Arab di Madrasah Ibtidaiyah kelas 6 dengan demikian memiliki peluang besar untuk mendapat kritik terkait tingkat konsistensi dan keselarasannya terutama terhadap aspek kurikulum lainnya yang dalam hal ini terkait pendekatan saintifik yang digunakan. Sejauh mana keselarasan di antara keduanya dapat dibaca dengan melakukan analisis kritis terhadap konten yang ada. Apakah memiliki ciri khas yang menunjukkan adanya penerapan saintifik atau tidak. Atau mungkin konten yang ada masih mempertahankan pendekatan lama yang berarti tidak ada perubahan di dalamnya, dan beberapa hal lain yang relevan untuk ditanyakan. Oleh karena itu, penelitian ini secara khusus berusaha untuk mengolaborasikan antara keseluruhan fakta sosial yang ada di atas dengan berbagai hal relevan terkait konsistensi antara pendekatan saintifik dengan kualitas mutu konten buku ajar ke dalam rangkaian deskripsi terstruktur

\footnotetext{
${ }^{2}$ Ibid, hlm. 150 .

${ }^{3}$ Santika Lya Diah Pramesti, Analisis Materi Dan Penyajian Buku Teks Matematika Sebagai Sumber Belajar Matematika, Delta: Jurnal Ilmiah Pendidikan Matematika 5, no. 1, 2017, hlm. $25-32$.
} 
yang dapat dipertanggungjawabkan secara ilmiah. Hipotesa umum yang muncul di tengah masyarakat terkait adanya inkonsistensi antara pendekatan dengan konten buku ajar bahasa Arab Madrasah Ibtidaiyah dapat dijawab, disanggah, atau bahkan mungkin dikuatkan dengan data ilmiah yang ada.

\section{B. Metode Penelitian}

Metode yang digunakan dalam penelitian ini yaitu metode penelitian deskriptifkualitatif mengingat bahwa permasalahan yang diangatkan dalam penelitian ini masih belum jelas, kompleks, dinamis, sehingga tidak memungkinkan untuk menggunakan metode penelitian kuantitatif. Selanjutnya untuk menyajikan keseluruhan data yang ada menjadi sebuah gambaran yang lengkap dan menyeluruh, peneliti mengkombinasikannya dengan metode penelitian deskriptif sehingga fakta apapun yang ditemukan terkait konsistensi antara pendekatan saintifik dengan konten pada buku bahasa Arab MI kurikulum 2013 dapat terbaca dengan baik dan jelas.

Adapun objek yang diteliti yaitu buku ajar bahasa Arab Madrasah Ibtidaiyah kelas 6 yang diterbitkan oleh Direktorat Pendidikan Madrasah Direktorat Jenderal Pendidikan Islam Kementerian Agama Republik Indonesia Tahun 2016 dengan judul Buku Siswa Bahasa Arab Pendekatan Saintifik Kurikulum 2013 Kelas 6 Madrasah Ibtidaiyah. Teknik pengumpulan data dengan dokumentasi melalui pembacaan secara menyeluruh terhadap buku tersebut kemudian melakukan pencatatan terkait hal-hal yang dianggap relevan dan dapat digunakan untuk mendeskripsikan tingkat konsistensi penggunaan pendekatan saintifik dengan konten pada buku bahasa Arab MI kelas 6 Kurikulum 2013 tersebut. Setelah itu dilakukan analisis data untuk melihat konsistensi penggunaan pendekatan saintifik pada buku ajar bahasa Arab MI kelas 6. Ini artinya teknik analisis data yang digunakan bersifat induktif, yaitu dengan melihat keseluruhan data yang ditemukan sebagai sumber acuan untuk melakukan pengembangan dan penelusuran terhadap adanya pola konsistensi dalam penerapan pendekatan saintifik pada buku bahasa Arab MI kelas 6 Kurikulum 2013.

Proses analisis data dilakukan sejak peneliti merumuskan dan menjelaskan masalah, sebelum melakukan pembacaan terhadap buku ajar yang digunakan sebagai objek penelitian, ketika melakukan pembacaan, saat dokumentasi, dan pasca dokumentasi. Berikut penjelasan terkait proses analisis data yang peneliti lakukan: 
1. Analisis ketika merumuskan dan menjelaskan masalah. Pada proses ini peneliti melakukan konstruksi terhadap berbagai fenomena sosial yang muncul mengemuka di tengah masyarakat terkait anggapan adanya inkonsistensi penerapan pendekatan saintifik pada buku ajar siswa MI. Selanjutnya keseluruhan konstruksi yang telah peneliti lakukan digunakan sebagai acuan hipotesis sekaligus untuk memetakan rumusan masalah yang akan diangkat.

2. Analisis sebelum melakukan pembacaan terhadap buku ajar. Pada proses ini peneliti memastikan bahwa buku ajar yang akan diteliti memang secara jelas mengklaim menggunakan pendekatan saintifik sebagai pendekatan utamanya.

3. Analisis saat melakukan pembacaan terhadap buku ajar. Pada proses ini peneliti melakukan pembacaan dalam rangka untuk mengetahui pola penyusunan buku ajar yang diteliti sekaligus mencari data-data yang relevan.

4. Analisis saat melakukan dokumentasi. Pada proses ini, peneliti melakukan dokumentasi dengan mencatat data-data yang dianggap relevan dan dimungkinkan relevan dengan melakukan kategorisasi sederhana menggunakan sebuah tabel.

5. Analisis setelah melakukan dokumentasi. Pada proses ini peneliti menganalisis keseluruhan data yang telah ditemukan dan menuangkannya dalam sebuah karya tulis ilmiah yang sistematis dan mudah dipahami.

\section{Hasil dan Pembahasan}

\section{a. Pendekatan Saintifik}

Pendekatan saintifik mulai diperkenalkan dan populer pertama kali di Amerika pada paruh akhir abad 19 sebagai pendekatan yang awalnya menekankan pada prinsip-prinsip metode laboratorium forensik dalam usaha mendapatkan fakta-fakta ilmiah. ${ }^{4}$ Di Indonesia sendiri pendekatan saintifik sebagai salah satu pendekatan yang paling digandrungi lembaga pendidikan Indonesia saat ini khususnya pada pengembangan Kurikulum 2013 yang mengupayakan pendekatan ini secara masif hingga tertuang pada standar proses Permendikbud No. 22 Tahun 2016. ${ }^{5}$ Pendekatan saintifik merupakan salah satu pendekatan yang secara khusus dirancang untuk membangun pola belajar aktif pada diri setiap peserta didik yang

4 Dika Setiawan, Pendekatan Saintifik Dan Penilaian Autentik Untuk Meningkatkan Mutu Pembelajaran Pendidikan Agama Islam, Al-Asasiyya: Journal of Basic Education 1, no. 2, 2017. hlm. 36.

${ }^{5}$ Wedra Aprison, Pendekatan Saintifik: Melihat Arah Pembangunan Karakter Dan Peradaban Bangsa Indonesia, Epistemé: Jurnal Pengembangan Ilmu Keislaman 12, no. 2, 2017, hlm. 32. 
kemudian diterjemahkan oleh Kementerian Pendidikan dan Kebudayaan dengan mengkategorikannya ke dalam lima langkah yang saling terkait, yaitu mengamati, menanya, mengumpulkan data, mengasosiasi, dan mengomunikasikan. ${ }^{6}$ Daryanto sebagaimana dikutip oleh Wahyu Lestari, dkk menuturkan bahwa secara ilmiah dapat dibuktikan peserta didik yang belajar menggunakan pendekatan ini umumnya dapat mengikuti kegiatan belajar mengajar dengan tingkat partisipasi aktif yang tinggi. ${ }^{7}$

Nurohmah sebagaimana dikutip oleh Adib Rifqi Setiawan secara tegas menjelaskan bahwasanya pendekatan ini memiliki tingkat efektifitas yang cukup tinggi terkait upaya peningkatan belajar peserta didik khususnya pada sisi aspek kognitif. Pada aspek ini jelas dapat dibuktikan secara ilmiah bahwa pendekatan ini berpengaruh pada perubahan pengetahuan, pemahaman dan kematangan dalam penerapan ilmu pengetahuan. ${ }^{8}$ Selaras dengan penjelasan ini yaitu sebagaimana dijelaskan oleh Nurul sebagaimana dikutip oleh yang menyebutkan bahwa pendekatan saintifik pada pembelajaran merupakan bentuk pendekatan ilmiah dan inkuiri yang berupaya membangun lingkungan belajar peserta didik yang memiliki peran secara aktif, langsung, mandiri baik secara kelompok maupun individu. Dengan adanya lingkungan belajar seperti ini peserta didik diharapkan dapat berupaya untuk menggali konsep dan prinsip-prinsip pengetahuan secara baik. ${ }^{9}$

A. Machin menegaskan bahwasanya tujuan pembelajaran strategis yang hendak diraih melalui pendekatan saintifik diantaranya adanya (1) peningkatan kemampuan dalam berfikir, (2) meningkatkan kemampuan menyelesaikan masalah secara benar dan sistematis, (3) membentuk kondisi belajar atau lingkungan belajar yang kondusif sehingga peserta didik secara naluriah merasa

${ }^{6}$ Sufairoh Sufairoh, Pendekatan Saintifik Dan Model Pembelajaran K-13, Jurnal Pendidikan Profesional 5, no. 3, 2017 .Pendekatan saintifik ini merupakan salah satu pendekatan yang direkomendasikan dalam K13 sebagaimana tercantum pada standar proses Permendikbud No. 22 Tahun 2016.

${ }^{7}$ Wahyu Lestari, Loviga Denny Pratama, and Jailani Jailani, Implementasi Pendekatan Saintifik Setting Kooperatif Tipe STAD Terhadap Motivasi Belajar Dan Prestasi Belajar Matematika, AKSIOMA: Jurnal Matematika Dan Pendidikan Matematika 9, no. 1, 2018, hlm. 29-36.

${ }^{8}$ Adib Rifqi Setiawan, Peningkatan Literasi Saintifik Melalui Pembelajaran Biologi Menggunakan Pendekatan Saintifik, Journal of Biology Education 2, no. 1, 2020, hlm.1-13.

9 Johari Marjan, Ida Bagus Putu Arnyana, and I Gusti Agung Nyoman Setiawan, Pengaruh Pembelajaran Pendekatan Saintifik Terhadap Hasil Belajar Biologi Dan Keterampilan Proses Sains Siswa MA. Mu Allimat NW Pancor Selong Kabupaten Lombok Timur Nusa Tenggara Barat, Jurnal Pendidikan Dan Pembelajaran IPA Indonesia 4, no. 1, 2014. 
butuh terhadap lingkungan tersebut, (4) memperoleh hasil pembelajaran yang ideal, (5) memberikan berbagai macam latihan kepada peserta didik untuk mengomunikasikan ide-ide mereka termasuk dalam hal ini yaitu mengembangkan karakter. ${ }^{10}$ Hosnan menjelaskan bahwa konstruksi pendekatan ini dapat diamati pada pelibatan proses kognitif yang strategis dan dinilai dapat menguatkan rangsangan bagi pengembangan kemampuan berfikir peserta didik. ${ }^{11}$ Sebagian kalangan menganggap bahwa pendekatan ini sangat identik dan relevan dengan beberapa teori belajar tiga orang ahli yaitu Piaget, Vygotsky, dan Bruner. ${ }^{12}$

Pada sisi pengembangan teori belajar Piaget, konstruksi pemahamannya tentang peserta didik cenderung melihat sebagai makhluk sosial yang secara alamiah memang tumbuh dalam suatu proses sosial yang besar dan terus-menerus. Dari sini kemudian Piaget membangun pemahaman bahwa pola belajar peserta didik diantaranya dengan memaksimalkan interaksi mereka pada lingkungan sosial dan fisik dengan materi-materi edukatif yang memposisikan peran pendidik sebagai fasilitator. Hal ini tentu saja bertujuan agar peserta didik dapat beradabtasi, berkoordinasi, belajar dan bahkan menghayati lingkungan sekitar dirinya. Hosnan mengemukakan bahwa proses adaptasi yang dapat dilakukan oleh peserta didik ada dua cara yaitu akomodasi dan asimilasi.

Pada teori belajar Vygotsky peran pendidik dipandang lebih central sebagai pembimbing yang dianggap memiliki kecakapan dan kematangan. Namun demikian titik pusat kegiatan belajar mengajar tidak hanya tertumpu pada pendidik melainkan berproses dengan mempertimbangkan lingkungan belajar yang baik dan mendukung. Antara pendidik dan peserta didik saling bertukar pendapat dan pengetahuan dalam mengurai suatu masalah tertentu. Selanjutnya pendidik atau peserta didik yang dianggap paling menonjol member bantuan kepada peserta didik lain yang mengalami kesulitan melalui petunjuk-petunjuk yang jelas. Ini artinya Vygotsky melihat pembelajaran sebagai proses interaksi-edukatif yang saling memberi dan menguntungkan dalam pendidikan. Kata kunci pada teori ini

${ }^{10}$ Achmad Machin, Implementasi Pendekatan Saintifik, Penanaman Karakter Dan Konservasi Pada Pembelajaran Materi Pertumbuhan, Jurnal Pendidikan IPA Indonesia 3, no. 1, 2014.

${ }^{11}$ Hosnan, Pendekatan Saintifik Dan Kontekstual Dalam Pembelajaran Abad 21, Jakarta: Ghalia Indonesia, 2014. hlm. 36.

${ }^{12}$ Yoserizal Bermawi and Tati Fauziah, Penerapan Pendekatan Saintifik Dalam Pembelajaran Di Sekolah Dasar Aceh Besar, Jurnal Pesona Dasar 2, no. 4, 2016. hlm. 65. 
yaitu peserta didik harus "kooperatif" dengan peserta didik lain sebagai lawan interaksi dan pendidik sebagai pendamping dan pembimbing yang dianggap lebih mampu. Sedangkan dalam teori belajar kognitif Brunner memiliki karakteristik teori yang khas dengan melihat peserta didik sebagai makhluk bebas sehingga secara langsung berimplikasi pada proses belajar yang mengarahkan untuk mandiri dan belajar secara discovery learning. ${ }^{13}$

Titik temu dari ketiga konsep belajar yang ditawarkan oleh masing-masing ahli dapat dilihat pada penjelasan Hosnan yang menggunakan kata kunci "peserta didik aktif' sebagai upaya yang harus didapatkan dalam setiap kegiatan belajar mengajar dengan mengikuti beberapa alur kerja belajar aktif mengupayakan peserta didik untuk melalui proses pengenalan, pengamatan, pengklasifikasian, pengukuran, peramalan, penjelasan, dan penyimpulan. Berikut beberapa pola dasar dari proses pembelajaran berbasis pendekatan saintifik:

1. Peserta didik diajarkan untuk melakukan observasi atau pengamatan terhadap suatu hal yang telah ditetapkan sebagai materi belajar. Proses ini mengutamakan meaningfull learning. ${ }^{14}$ Secara khusus bertujuan untuk melatih mereka menemukan makna pada suatu fenomena, fakta, atau apapun itu mulai dari yang bersifat sederhana hingga kompleks. Perta didik yang berhasil melalui proses ini diharapkan dapat memiliki ketelitian, kesungguhan, dan pengamatan yang baik terhadap suatu hal.

2. Peserta didik diajarkan untuk menanya. Proses ini membuka peluang pendidik memberikan kesempatan seluas-luasnya kepada peserta didik untuk bertanya tentang hal-hal relevan dalam suatu materi pelajaran terkait apa saja yang telah mereka saksikan, simak, pelajari, baik dari bangku sekolah maupun di luar sekolah seperti media elektronik, internet, dan lain sebagainya. Kegiatan bertanya merupakan bagian yang tidak dapat dipisahkan dalam pendekatan saintifik karena peserta didik akan diajarkan untuk menggali informasi dan mengomunikasikannya kepada orang lain, sehingga mereka akan menjadi manusia yang kreatif, memiliki rasa ingin tahu yang besar, dan piawai dalam merumuskan suatu pertanyaan kritis.

\footnotetext{
${ }^{13}$ Hosnan, Pendekatan Saintifik Dan Kontekstual Dalam Pembelajaran Abad 21. hlm. 35.

14 Setiawan, Pendekatan Saintifik Dan Penilaian Autentik Untuk Meningkatkan Mutu Pembelajaran Pendidikan Agama Islam." hlm. 38.
} 
3. Peserta didik diajarkan untuk mengumpulkan data-data. Informasi dan data merupakan dua hal yang saling terkait. Ketika peserta didik dituntut untuk memiliki dan mengkritisi suatu informasi berarti pada dasarnya mereka harus pula memiliki dan menggunakan data. Oleh karena itu pada proses pembelajaran ini, peserta didik diajak untuk menggali dan mengumpulkan berbagai macam informasi melalui beragam cara misalnya dengan memperhatikan suatu objek relevan, membaca artikel di internet, buku, atau media pembelajaran lainnya. Dengan adanya rangkaian upaya ini diharapkan mereka dapat menjadi sosok yang teliti, mampu melihat sesuatu secar proporsional, dan objektif.

4. Peserta didik diajarkan untuk mengasosiasi, mengolah, dan menalar informasi. Tiga proses sistematis ini merupakan kelanjutan dari proses sebelumnya yang merupakan satu kesatuan yang tidak dapat dipisahkan. Kegiatan ini dilakukan untuk melihat ada tidaknya suatu kaitan antara satu objek dengan objek lainnya. Apabila keterkaitan ini dapat dilihat dengan baik, peserta didik diharapkan dapat melihat pola dari adanya unsur-unsur saling terkait tersebut.

5. Peserta didik diajak untuk selalu mengkomunikasikan apa saja yang telah dipelajari. Proses ini tentu saja merupakan bentuk peran aktif peserta didik dalam rangka untuk mencari titik kedewasaan mereka dalam satu interaksi sosial yang memiliki tujuan pembelajaran dan pendidikan. Proses ini tidak dapat diupayakan oleh satu pihak saja, namun harus diupayakan oleh seluruh anggota kelas dalam suatu kegiatan belajar. Seorang pendidik tidak dapat disebut telah sukses mengelola kelas aktif-komunikatif apabila hanya dirinya yang berbicara di depan kelas. Demikian pula sebaliknya. Proses aktif-komunikatif dapat berjalan apabila seluruh unsur yang ada saling berkomunikasi untuk belajar. Pada sisi ini, misalnya peserta didik dapat menceritakan secara aktif apa yang mereka temukan, melakukan presentasi, dan lain sebagainya yang kemudian ditanggapi secara baik oleh pendidik.

Langkah-langkah di atas merupakan langkah-langkah yang khas dalam pendekatan saintifik. Dika Setiawan menyebutnya sebagai memiliki karakteristik doing science ${ }^{15}$ yang dapat dilihat pada beberapa perolehan sikap, pengetahuan dan keterampilan berikut ini:

\footnotetext{
${ }^{15}$ Setiawan. hlm. 36-37.
} 
1. Pada aspek sikap diharapkan peserta didik dapat memiliki kematangan pada sikap menerima, menjalankan, menghargai, menghayati, dan mengamalkan

2. Pada aspek pengetahuan diharapkan peserta didik dapat memiliki kemampuan untuk mengingat, memahami, menerapkan, menganalisis, mengevaluasi, dan mencipta

3. Pada aspek keterampilan diharapkan peserta didik dapat memperoleh kemampuan untuk mengamati, menanya, mencoba, menalara, menyaji, dan mencipta. $^{16}$

Sebetulnya standarisasi terkait buku ajar telah diupayakan oleh BSNP atau Badan Standar Nasional Pendidikan yang secara jelas mengatur delapan standar pendidikan, yaitu; standar pengelolaan, standar kompetensi lulusan, standar isi, standar proses, standar penilaian, standar pendidik dan tenaga pendidik, standar sarana prasarana, dan standar biaya. Khusus terkait standar isi, berdasarkan pada Peraturan Menteri Pendidikan dan Kebudayaan Republik Indonesia Nomor 21 Tahun 2016 Tentang Standar Isi Pendidikan Dasar dan Menengah yang diantara isinya pada pasal 1 ayat 1 dikatakan "Standar isi untuk pendidikan dasar dan menengah yang selanjutnya disebut Standar Isi terdiri dari Tingkat Kompetensi dan Kompetensi Inti sesuai dengan jenjang dan jenis pendidikan tertentu." Pada penjabaran terkait maksud standar isi pendidikan dasar dan menengah ini, pada bab I Pendahuluan secara jelas dikatakan perlu adanya kesesuaian antara standar isi dengan ruang lingkup materi dan kompetensi peserta didik. Secara filosofis-praktis, tuntutan untuk membangun "kesesuaian" antara kompetensi dengan jenjang pendidikan ini berarti mengisyaratkan pentingnya konsistensi antara berbagai hal yang terkait termasuk dalam hal ini kesesuaian antara pendekatan yang digunakan dalam penyusunan buku ajar dengan konten pada buku ajar itu sendiri.

Namun demikian, keseluruhan upaya BSNP yang sudah semestinya mendapatkan apresiasi sebesar-besarnya tidak serta merta menyurutkan proses kritis melaluia standar penelitian ilmiah untuk mengawal, memberi kritik dan masukan konstruktif, serta sebagai upaya edukatif kepada masyarakat luas, stakeholder, maupun pelaku pendidikan untuk melihat suatu fenomena perubahan kurikulum pendidikan secara luas, menyeluruh dan objektif. Adanya asumsi kekurangan harus

16 PPPPTK-SB Yogyakarta, Materi Pelatihan Implementasi Kurikulum 2013 Untuk Pengawas Sekolah, Jakarta: Penerbit Kementerian Pendidikan dan Kerbudayaan RI, 2013. 
dihadirkan dan dinarasikan secara objektif, demikian pula adanya kelebihan dan keberhasilan juga perlu dihadirkan dan dinarasikan secara objektif.

\section{b. Konten Buku Ajar Bahasa Arab Kelas 6 MI}

Buku ajar bahasa Arab kelas 6 MI terdiri atas lima bab dengan penyebutan untuk masing-masing bab yaitu al Dars al Awwal, al Dars al Tsani, al Dars al Tsalits, al Dars al Rabi', dan al Dars al Khamis. Pada bab pertama sampai pada bab lima konten yang disuguhkan relatif konsisten yaitu terkait materi mufrodat, istima', hiwar, qira'ah, tadribat, kitabah, tarkib, dan tamrinat. Adapun uji kompetensi semester satu dilakukan setelah peserta didik menyelesaikan bab 3 dan uji kompetensi semester dua setelah selesai bab lima. Ini artinya pada semester pertama peserta didik akan belajar tiga bab materi, dan pada semester dua mereka akan belajar dua bab materi. Berikut keseluruhan tema besar yang terdapat pada masing-masing bab:

1. Tema bab pertama tentang a'maluna fi al madrasah wa al bait

2. Kam al sa'ah wa fi ai sa'ah

3. Ta'lamu al lughah al 'arabiyah

4. Al wajib al manzili

5. Al nuzhah

Pada bab pertama peserta didik akan belajar tentang tema besar a'maluna $f i$ al madrasah wa al bait (aktifitas kami di sekolah dan rumah). Tugas pertama yang diberikan pada bab ini yaitu tugas untuk mengamati dan menceritakan gambar yang telah disajikan pada buku ajar dengan menggunakan bahasa Arab. sebaagai alat bantu, di bawah butir tugas tersedia kumpulan mufrodat yang terdiri dari 16 fi 'il. Pada butir tugas kedua, peserta didik diminta untuk memperhatikan dan memahami makna ujaran yang tertera pada buku ajar. Setelah itu mereka diminta untuk menyebutkan macam-macam pekerjaan di madrasah dan rumah. Pada butir tugas ketiga, perta didik diminta untuk mendengarkan dan menirukan bacaan guru. Sebagai contoh guru membaca nudzakru al durus fi ghurfah al mudzakarah kemudian peserta didik menirukannya. Pada butir tugas keempat, peserta didik diajarkan tentang hiwar atau percakapan dengan judul ajri al hiwar ma'a shadiqika amama al fashl sebuah perintah untuk mempraktikkan percakapan menggunakan bahasa Arab di depan kelas. 
Pada butir tugas kelima bab pertama, peserta didik mendapatkan materi qira'ah dengan judul a'maluna fi al madrasah wa al bait dilanjutkan tugas tadribat yaitu menjawab soal-soal yang berkaitan dengan qira'ah di atas. Pada butir tugas keenam, peserta didik diajak untuk membaca dan memahami kalimat-kalimat yang disajikan dalam buku ajar. Misalnya pembacaan dan pemahaman terhadap kalimat ana aktubu al dars. Pada butir tugas ketujuh, peserta didik diminta untuk menulis kalimat sempurna dari beberapa kata yang telah ditentukan dilanjutkan tugas penyusunan kata-kata acak ke dalam bentuk kalimat sempurna.

Pada butir tugas kedelapan, peserta didik diminta untuk menerjemahkan kalimat berbahasa Indonesia ke dalam bahasa Arab dengan baik dan benar, menyebutkan beberapa aktifitas yang seharusnya dilakukan agar seluruh pekerjaan di madrasah dan di rumah terlaksana dengan baik, dan memberikan checklist pada beberapa pernyataan yang disediakan dengan salah satu jawaban antara setuju, raguragu, tidak setuju.

Selanjutnya pada butir tugas kesembilan, peserta didik mendapatkan sajian materi tarkib tentang pengertian fi'il mudhari', perubahan bentuk dalam fi'il mudhari' disesuaikan dengan pelaku yang mengerjakan suatu perbuatan, dan tandatanda fi'il mudhari'. Kemudian peserta didik akan mendapatkan tugas untuk merubah fi'il mudhari' sesuai dengan kata ganti yang ditentukan. Misal kata kerja aktubu (saya menulis) harus dirubah ke dalam bentuk kata yang memiliki arti dia (lk) menulis.

Tugas kesembilan merupakan tugas terakhir yang harus diselesaikan oleh peserta didik pada bab pertama ini. Setelah itu mereka diarahkan untuk mengerjakan tamrinat semacam ujian berkala sebelum lanjut materi bab dua. Pada tamrinat ini peserta didik mendapatkan beberapa bentuk soal dengan panduan pada masingmasing bentuk soal sebagai berikut:

1. ikhtar al huruf alif, ba', jim, au dal, li al ajwibah al shahihah

2. imla' al firagh bi al af'al al munasibah al atiyah

3. ajib 'an al asilah al atiyah

4. tarjim al jumal al atiyah bi al lughah al indunisiyah

5. tarjim al jumal al atiyah bi al lughah al 'arabiyah 
Pada bab selanjutnya yakni kedua sampai kelima, bentuk penugasan yang terdapat di masing-masing bab tersebut hampir sama dengan apa yang terdapat pada bab pertama yang mana terdiri dari Sembilan butir dan ditutup dengan tamrinat sebagai ujian berkala atau ulangan harian sebelum masuk pada bab selanjutnya. Oleh karena itu peneliti tidak mendeskripsikan keseluruhan bab sebagai bentuk efisiensi. Peneliti hanya mendeskripsikan bab pertama sebagai gambaran umum konten buku ajar bahasa Arab yang disajikan untuk kelas $6 \mathrm{MI}$ ini.

\section{c. Konsistensi Pendekatan Saintifik Pada Buku Ajar Bahasa Arab kelas 6 MI}

Konsistensi pendekatan saintifik pada buku ajar bahasa Arab kelas 6 MI dapat kita kategorikan keseluruhan bentuk tugas yang ada pada masing-masing bab dalam buku ajar tersebut dengan kategori tugas ke-1, ke,2, dan selanjutnya hingga ke-9. Selanjutnya digunakan kode KT1, KT2, KT3, KT4, KT5, KT6, KT7, KT8, dan KT9.

Masing-masing kategori tugas ini akan dianalisis apakah konsisten menggunakan pendekatan saintifik ataukah tidak. Untuk menjawabnya persoalan ini kita dapat mengetahuinya dengan memperhatikan perintah yang diberikan pada masing-masing KT kemudian mengaitkannya dengan konsep teoritis pendekatan saintifik itu sendiri. Dan berikut hasil dari analisis selengkapnya:

1. Pada KT1, tugas yang diberikan telah sesuai dengan pendekatan saintifik. Berdasarkan pada deskripsi konten buku bahasa Arab kelas 6 MI pada sub bab di atas dapat dilihat bahwa pada poin tugas pertama yang harus dikerjakan oleh peserta didik yaitu terkait pengamatan atau observasi sederhana tentang gambar yang harus diberikan suatu makna oleh setiap peserta didik dengan metode bercerita dengan menggunakan bahasa Arab. Untuk mempermudah dalam pembentukan kalimat, peserta didik dibantu dengan kumpulan mufradat yang terdapat pada tabel di bawahnya. Tugas ini sesuai dengan tipe pendekatan saintifik yang mengupayakan peserta didik untuk aktif dalam melakukan pengamatan yang diantara tujuannya untuk mencapai kebermaknaan dari kegiatan belajar mengajar itu sendiri.

2. Pada KT2, peserta didik diperintahkan untuk memperhatikan dan mengamati makna ujaran dalam bahasa Arab kemudian diminta untuk menyebutkan macam pekerjaan di sekolah dan di rumah. Proses pengamatan terhadap ujaran 
berbahasa Arab merupakan bentuk pembelajaran menggunakan pendekatan saintifik, sebab pada model KT ini pendidik dapat memberikan peluang bagi peserta didik untuk melakukan pengamatan, melatih mereka memperhatikan bagaimana menggunakan ujaran dengan bahasa Arab, selanjutnya melakukan pengamatan terhadap suatu fenomena sosial berupa aktifitas nyata yang seringkali terjadi di rumah dan di sekolah sebagai rutinitas bentuk pekerjaan yang terjadi.

3. Pada KT3, tugas yang harus dikerjakan oleh peserta didik yaitu mendengarkan dan menirukan bacaan guru dengan menggunakan bahasa Arab. Pada KT ini pendidik cenderung menggunakan fungsinya sebagai pemandu bagi yang berusaha memantik sikap aktif peserta didik untuk mencoba. Hal ini selaras dengan pendekatan saintifik dalam pembelajaran yang menekankan upaya untuk melakukan "percobaan" berujar dengan memperhatikan ujaran pendidik. Dalam pendekatan saintifik $5 \mathrm{M}$ yang dimaksud yaitu mengamati, menanya, menalar, mencoba, dan membentuk jejaring.

4. Pada KT4 peserta didik diminta untuk mempraktikkan percakapan dengan bahasa Arab di depan kelas. Tipe KT ini hampir mirip dengan KT sebelumnya yang mendorong peserta didik untuk mencoba melakukan sesuatu yang baru yang dalam hal ini yaitu percakapan tentang tema tertentu dengan bahasa Arab. Perbedaan dengan KT sebelumnya, pada KT4 guru tidak menggunakan fungsinya sebagai fasilitator tetapi sebatas sebagai pengamat yang mengamati proses belajar yang dilakukan peserta didik secara mandiri melalui khiwar.

5. Pada KT5 tugas yang diberikan yaitu qira'ah dan menjawab pertanyan seputar tema qira'ah. Ini artinya pada KT ini peserta didik diminta untuk membaca secara jahr suatu bacaan dengan menggunakan bahasa Arab kemudian menjawab pertanyaan yang relevan dengan apa yang telah mereka baca. Bentuk KT ini juga dapat dikategorikan sebagai pendekatan saintifik yang mengupayakan peserta didik untuk meningkatkan keterampilan membaca, berbicara, dan member jawaban secara logis, tepat, sistematis, dan menggunakan bahasa yang benar sesuai standar gramatika Arab. 
6. Pada KT6 pesertadidik mendapatkan tugas untuk membaca dan memahami kalimat berbahasa Arab. Bentuk KT6 ini hampir sama dengan bentuk KT5 hanya perbededaannya pada KT6 dilengkapi dengan gambar.

7. Pada KT7 tugas yang diberikan juga selaras dengan pendekatan saintifik yang mana peserta didik diminta untuk melakukan penalaraan terhadap kalimat berbahasa Arab yang belum sempurna dan bentuk kata-kata acak yang harus disusun ke bentuk kalimat sempurna. Proses penalaran pada KT ini merupakan bentuk pendekatan saintifik yang mengajarkan peserta didik untuk dapat berfikir secara logis dan sistematis atas fakta empiris berupa kumpulan kata dan rangkaian kalimat tidak sempurna yang kemudian dilakukan observasi dan penalaran logis sehingga menjadi kalimat yang baik dan sempurna.

8. Pada KT8 peserta didik diminta untuk menerjemahkan teks, melakukan observasi terhadap beberapa aktifitas yang relevan agar suatu pekerjaan dapat terlaksana dengan baik dan terakhir memberikan checklist pada beberapa pertanyaan dengan salah satu jawaban antara setuju, ragu-ragu dan tidak setuju. KT ini secara umum dapat dikatakan menggunakan pendekatan saintifik yang mana peserta didik diajarkan untuk mengasosiasikan berbagai informasi guna menemukan jawaban yang relevan. Sebagai contoh untuk menjawab pertanyan tentang aktivitas apa saja yang perlu dilakukan di sekolah agar tugas sekolah dapat selesai dengan baik maka peserta didik didorong untuk aktif berfikir, menalar, atas fakta-fakta empiris yang dapat diobservasi secara sederhana terkait aktifitas ideal yang harus dimiliki seorang pelajar ketika menyelesaiakan tugas di sekolah. Selain itu pada KT ini peserta didik juga diajarkan untuk mengkomunikasikan apa yang telah dipelajari dengan guru/pendidik dengan cara memberikan checklist terhadap beberapa pertanyaan seputar attitude yang diajukan. Adanya tugas checklist terhadap pertanyaan model ini pada pendekatan saintifik digunakan untuk mengaitkan antara ranah sikap dengan substansi materi yang diajarkan sebelumnya. ${ }^{17}$

9. Pada KT9 tugas yang diberikan yaitu terkait tamrinat atau semacam ujian berkala yang harus diselesaikan oleh peserta didik. Tugas ini secara umum merupakan bagian dari proses menalar terhadap berbagai macam pertanyaan

17 Eka Aprilia Permatasari, Implementasi Pendekatan Saintifik Dalam Kurikulum 2013 Pada Pembelajaran Sejarah, Indonesian Journal of History Education 3, no. 1, 2014. hlm. 12. 
Konsistensi Pendekatan...

yang diajukan. KT ini juga merupakan bagian paling penting dari proses evaluasi terhadap terhadap kegiatan belajar mengajar pada setiap bab.

\section{Simpulan}

Dari proses analisis yang telah dilakukan dapat dilihat bahwasanya hipotesis kritis terkait inkonsistensi pendekatan saintifik pada buku ajar bahasa Arab kelas 6 MI tidak terbukti. Sebaliknya, hasil penelitian menunjukkan adanya konsistensi dari penggunaan pendekatan saintifik mulai dari bab pertama hingga bab kelima (terakhir). Hanya konsistensi yang ada tidak berbanding lurus dengan kualitas konten buku ajar yang ada karena masih terlihat monoton, kurang variatif antara bentuk tugas pada masing-masing bab. Untuk itu penelitian ini selain mengupayakan untuk menjawab hipotesis juga memberikan rekomendasi kepada pihak terkait untuk melakukan revisi buku ajar yang telah ada dengan membuat konten tugas yang bervariasi, tidak monoton, sehingga peserta didik dapat lebih tertarik untuk belajar bahasa Arab.

\section{DAFTAR PUSTAKA}

Aprison, Wedra, Pendekatan Saintifik: Melihat Arah Pembangunan Karakter Dan Peradaban Bangsa Indonesia. Epistemé: Jurnal Pengembangan Ilmu Keislaman 12 , no. $2,2017$.

Bermawi, Yoserizal, and Tati Fauziah, Penerapan Pendekatan Saintifik Dalam Pembelajaran Di Sekolah Dasar Aceh Besar, Jurnal Pesona Dasar 2, no. 4, 2016)\. Hosnan. Pendekatan Saintifik Dan Kontekstual Dalam Pembelajaran Abad 21. Jakarta: Ghalia Indonesia, 2014.

Langgulung, Hasan. Manusia \& Pendidikan Suatu Analisa Psikologis. Jakarta: PT. Al Husna Baru, 2004.

Lestari, Wahyu, Loviga Denny Pratama, and Jailani Jailani, Implementasi Pendekatan Saintifik Setting Kooperatif Tipe STAD Terhadap Motivasi Belajar Dan Prestasi Belajar Matematika, AKSIOMA: Jurnal Matematika Dan Pendidikan Matematika 9, no. 1, 2018.

Machin, Achmad, Implementasi Pendekatan Saintifik, Penanaman Karakter Dan Konservasi Pada Pembelajaran Materi Pertumbuhan, Jurnal Pendidikan IPA Indonesia 3, no. 1, 2014. 
Muhammad Zaairul Haq

Marjan, Johari, Ida Bagus Putu Arnyana, and I Gusti Agung Nyoman Setiawan. Pengaruh Pembelajaran Pendekatan Saintifik Terhadap Hasil Belajar Biologi Dan Keterampilan Proses Sains Siswa MA. Mu Allimat NW Pancor Selong Kabupaten Lombok Timur Nusa Tenggara Barat, Jurnal Pendidikan Dan Pembelajaran IPA Indonesia 4, no. 1, 2014.

Permatasari, Eka Aprilia, Implementasi Pendekatan Saintifik Dalam Kurikulum 2013 Pada Pembelajaran Sejarah, Indonesian Journal of History Education 3, no. 1, 2014.

PPPPTK-SB Yogyakarta, Materi Pelatihan Implementasi Kurikulum 2013 Untuk Pengawas Sekolah. Jakarta: Penerbit Kementerian Pendidikan dan Kerbudayaan RI, 2013.

Pramesti, Santika Lya Diah, Analisis Materi Dan Penyajian Buku Teks Matematika Sebagai Sumber Belajar Matematika, Delta: Jurnal Ilmiah Pendidikan Matematika 5, no. $1,2017$.

Setiawan, Adib Rifqi, Peningkatan Literasi Saintifik Melalui Pembelajaran Biologi Menggunakan Pendekatan Saintifik, Journal of Biology Education 2, no. 1, 2020.

Setiawan, Dika, Pendekatan Saintifik Dan Penilaian Autentik Untuk Meningkatkan Mutu Pembelajaran Pendidikan Agama Islam, Al-Asasiyya: Journal of Basic Education 1, no. 2, 2017.

Sufairoh, Sufairoh, Pendekatan Saintifik Dan Model Pembelajaran K-13, Jurnal Pendidikan Profesional 5, no. 3, 2017. 